\title{
Pengaruh Pendidikan Gizi Terhadap Pengetahuan, Sikap Dan Perilaku Konsumsi Pangan Isoflavon Pada Mahasiswi Pre-Menstrual Syndrome
}

\section{Effect of Nutrition Education on Knowledge, Attitude and Behavior in Consuming Isoflavones Rich Food among Female Students with Pre-Menstrual Syndrome}

\author{
Dhiflatul Frista Anani*, Trias Mahmudiono ${ }^{1}$
}

\begin{abstract}
ABSTRAK
Latar belakang: Kelompok umur yang rentan mengalami gejala Pre-Menstrual Syndrome dimulai pada tahap awal pubertas dan berakhir pada tahap menopause. Patofisiologi Pre-Menstrual Syndrome terjadi karena ketidakseimbangan hormon estrogen dan progesteron. Salah satu penyeimbang kedua hormon yaitu konsumsi pangan isoflavon karena struktur dan sifatnya menyerupai estrogen.

Tujuan: Penelitian ini bertujuan untuk untuk menganalisis pengaruh pendidikan gizi terhadap pengetahuan, sikap dan perilakukonsumsi pangan tinggi kadar isoflavon pada mahasiswi dengan premenstrual syndrome.

Metode: Penelitian ini merupakan penelitianquasi experiment dengan pendekatan pre-post control group design. Rancang bangun penelitian ini yaitu pemberian intervensi pendidikan gizi $4 x$ pertemuan selama 1 bulan dengan durasi masing-masing pertemuan 60 menit dan pemberian susu kedelai setiap pertemuan. Tehnik sampel menggunakan simple random sampling total 38 responden dibagi menjadi 2 kelompok (kelompok perlakuan dan kontrol). Skrining awal untuk menilai PMS menggunakan kuesioner Shortened Pramenstrual Assessment Form (SPAF). Variabel dependen adalah pengetahuan, sikap dan perilaku konsumsi pangan isoflavon, sedangkan variabel independen pendidikan gizi. Analisis yang dilakukan menggunakan uji t Independent.

Hasil: Setelah diberikan pendidikan gizi terdapat perbedaan signifkan tingkat pegetahuan dan sikap antara kelompok perlakuan dan kontrol dengan nilai $p$ masing-masing 0,039 dan 0,022. Selain itu juga terdapat perbedaan perilaku konsumsi pangan tinggi kadar isoflavon mayoritas jenis makanan sering dikonsumsi meliputi:tempe goreng $(p=0,044)$, tahu $(p=0,036)$, bawang putih $(p=0,014)$ es susu kedelai $(p=0,044)$ dan susu kedelai $(p=0,004)$.

Kesimpulan: Pemberian intervensi pendidikan gizi kepada kelompok perlakuan dapat merubah pengetahuan, sikap dan perilaku konsumsi pangan tinggi kadar isoflavon, dengan adanya perilaku konsumsi yang meningkat, maka gejala pre-menstrual syndrome pada mahasiswi FKM UNAIR juga menurun secara perlahan. Walaupun belum semua jenis makanan yang tinggi kadar isoflavon dikonsumsi oleh responden dikarenakan keterbatasan waktu penelitian.
\end{abstract}

Kata Kunci: pendidikan gizi, pengetahuan, sikap, perilaku, isoflavon, pre-menstrual syndrome 


\section{ABSTRACT}

Background: The age group susceptible to symptoms of Pre-Menstrual Syndrome begins in the early stages of puberty and ends at the menopause stage. The pathophysiology of Pre-Menstrual Syndrome is due to an imbalance of estrogen and progesterone hormones. One of the balancers of both hormones is the consumption of isoflavone food because the structure and its properties resemble estrogen.

Objectives: The Purpose of this study was to analyzed the effect of nutritional education on the knowledge, attitude and behavior high food consumption of isoflavone content among female premenstrual syndrome.

Method: The study was quasy experiment with pre- post control group design. The design of this research was the provision of nutrition education four times for 1 month with duration of each meeting 60 minutes and the provision of soy milk every meeting. The sample technique using simple random sampling total 38 respondents divided into 2 groups (treatment and control group). Preliminary screening to assess PMS using the Shortened Pramenstrual Assessment Form (SPAF) questionnaire. Dependent variable was knowledge, attitude and consumption behavior of isoflavone food, while independent variable was nutrition education.The analysis was performed using Independent t-test.

Result: After nutrition education there was significant difference of knowledge and attitude level between treatment and control group respectively $p$ value 0.039 and 0.022 . In addition, there were also differences in high food consumption behavior of isoflavone content. The majority of food types are often consumed including: fried tempeh $(p=0.044)$, tofu $(p=0.036)$, garlic $(p=0.014)$ ice soybean milk $(p=0.044)$ and soybean milk $(p=0.004)$.

Conclusion: Provision of nutrition education to the treatment group can change knowledge, attitude and behavior of high food consumption of isoflavone content, with the existence of increasing consumption behavior, than pre-menstrual syndrome symptoms at student of FKM UNAIR decreased slowly. Although not all types of foods high levels of isoflavones consumed by respondents due to limited time research.

Keywords: nutrition education, knowledge, attitude, behaviour, isoflavones, pre-menstrual syndrome

\footnotetext{
*Koresponden:

dhiflatul.frista.anani-2015@fkm.unair.ac.id

${ }^{1}$ Program studi S1 Ilmu Kesehatan Masyarakat,

Universitas Airlangga, Indonesia
}

\section{PENDAHULUAN}

Wanita normal akan mengalami peristiwa reproduksi secara periodik setiap bulan yang disebut dengan menstruasi. Menstruasi pada wanita biasanya mulai umur 12-15 tahun,sedangkan siklus menstruasi yang normal sekitar 28 hari dengan rentang waktu 21-35 hari. Siklus menstruasi wanita bervariasi tergantung dari pengaruh fisik, psikis dan intake asupan gizinya. Beberapa wanita mengalami beberapa macam gangguan menstruasi meliputi: gangguan pada siklus menstruasi, disminorhea dan Pre-Menstrual Syndrome (PMS). Pre-Menstrual Syndrome adalah gangguan yang terjadi pada wanita muda sampai pertengahan yang ditandai dengan gejala fisik, gejala psikologis, emosi yang terjadi selama akhir fase luteal dalam siklus menstruasi sampai dengan awal 
menstruasi atau dapat berlangsung sampai menstruasi berhenti. ${ }^{1}$

Kelompok umur yang rentan mengalami gejala Pre-Menstrual Syndrome yaitu pada masa produktif kalangan wanita dengan rentang usia 20-50 tahun mulai dari masa pubertas sampai tahap menopause. Selama masa reproduksi, sekitar $80-90 \%$ wanita yang menstruasi mengalami beberapa gejala seperti nyeri payudara, sembelit, kembung, jerawat, yang menandakan akan dimulai menstruasi yang dinamakan Pre-Menstrual Syndrome. Gejala tersebut akan mempengaruhi perubahan perilaku sehingga akan menyebabkan gejala yang parah dan dapat mengganggu aktivitas sehari-hari. Faktor penyebab dari Pre-Menstrual Syndrome adalah faktor hormonal (ketidakseimbangan antara hormon estrogen dan progesteron), faktor kimiawi (fungsi kerja serotonin yang ada didalam otak berubahubah selama siklus menstruasi), faktor genetik, faktor psikologis, faktor gaya hidup (pola makan, intake gizi yang masuk dalam tubuh). ${ }^{1}$

Faktor pemicu terjadinya Pre-Menstrual Syndrome erat kaitanya dengan ketidakseimbangan hormon. Kandungan isoflavon merupakan turunan dari fitoestrogen yang dapat diserap kedalam tubuh dan mengalami berbagai perubahan seperti dapat disekresikan atau dipecah menjadi komponen-komponen lain dalam tubuh yang masih mengandung khasiat menyerupai estrogen. ${ }^{2}$ Terdapat satu jenis tanaman dapat mengandung lebih dari satu jenis zat aktif fitoestrogen, misalnya kacang kedelai banyak mengandung isoflavon. ${ }^{3}$ Perilaku konsumsi pangan bersumber isoflavon terhadap kejadian Pre-Menstrual Syndrome pada kalangan wanita dapat di analisis salah satunya dengan menggunakan pendidikan gizi berbasis Social Cognitive Theory. Teori ini mengklaim teori pembelajaran sosial yang menunjukkan adanya korelasi langsung antara self efficacy, lingkungan dan perubahan perilaku seseorang. ${ }^{4}$ Pendidikan gizi memfasilitasi perilaku kondusif untuk kesehatan dengan memusatkan perhatian pada motivasi pribadi dan kompetensi, interaksi interpersonal, dan faktor lingkungan yang difokuskan untuk mempengaruhi perilaku individu dan masyarakat. ${ }^{5}$ Pengontrolan gejala PMS dapat dilakukan dengan program pendidikan gizi. Penggunaan metode pendidikan gizi selama lebih dari 1 bulan dapat menurunkan gejala pre-menstrual syndrome. ${ }^{6}$

Berdasarkan studi pendahuluan pada mahasiswi Alih Jenis Fakultas Kesehatan Masyarakat Universitas Airlangga dari 20 mahasiswi, sebesar $60 \%$ dengan jumlah 12 mahasiswi mengalami Pre-Menstrual Syndrome sedang. Dilihat dari tingkat gejala PMS, untuk PMS ringan sebesar $40 \%$ dengan jumlah 8 responden, untuk PMS sedang sebesar $60 \%$ dengan jumlah12 responden dan untuk PMS berat tidak ditemukan. Gejala PMS rata-rata yang paling sering dialami oleh mahasiswi adalah nyeri payudara, nyeri punggung, otot, sendi, mudah marah dan nyeri bagian perut. Kebanyakan mahasiswi mengalami gejala PMS dikarenakan aktivitas mahasiswi dikampus seperti kegiatan-kegiatan kampus, padat tugas pada setiap mata kuliah sehingga memerlukan tenaga untuk berfikir. Selain itu, dari padatnya aktivitas mahasiswi akan mengurangi konsumsi makan yang seharusnya dikonsumsi. Hasil FGD (Focus Group Discussion) bersama 8 mahasiswi FKM UNAIR dengan metode wawancara FFQ (Food Frequency Questionare) diperoleh bahwa, frekuensi dan keberagaman mahasiswi dalam memilah dan mengkonsumsi makanan yang mengandung kadar isoflavon masih tergolong kurang walaupun telah mendapatkan materi tentang pre-menstrual syndrome akan tetapi masih banyak yang belum mengetahui cara penanganan yang tepat untuk mengurangi gejala pre-menstrual syndrome. Cara mahasiswi dalam mengkonsumsi pangan rendah kandungan isoflavon masih monoton sehingga dapat mempengaruhi kejadian PreMenstrual Syndrome yang dialami oleh mahasiswi. Faktor kelalaian tidak menjadi faktor utama bagi individu dalam 
mengkonsumsi pangan isoflavon akan tetapi dapat dikarenakan mindset mahasiswi terkait ketersediaan dan akses pangan sumber isoflavon dianggap hal yang biasa karena mudah didapatkan.

Faktor yang berhubungan dengan konsumsi isoflavon pada wanita adalah pengetahuan, sikap dan perilaku, selain itu ada beberapa faktor lain yang dapat mempengaruhi konsumsi pangan isoflavon yaitu budaya, peran orang tua, peran teman sebaya, media pendidikan gizi, psikologis, jenis makanan penghambat asupan isoflavon dalam tubuh (soda, kafein, gula dan garam). Pada penelitian sebelumnya dijelaskan bahwa konsumsi garam, gula, soda dan kafein yang berlebih dapat menghambat asupan isoflavon dalam tubuh karena dapat meyebabkan gangguan metabolisme dan suasana hati sehingga berisiko memiliki peluang 2,279 kali lebih besar untuk mengalami pre-mestrual syndrome. $^{7}$

Berdasarkan latar belakang diatas terjadinya pre-menstrual syndrome pada mahasiswi erat kaitannya dengan pengetahuan, sikap dan perilaku mahasiswi dalam mengkonsumsi pangan yang mengandung tinggi kadar isoflavon. Penulis tertarik untuk menganalisis perbedaan pengetahuan, sikap, dan perilaku konsumsi pangan sebelum dan sesudah dilakukan intervensi pendidikan gizi tentang pangan isoflavon pada mahasiswi Alih Jenis Fakultas Kesehatan Masyarakat Universitas Airlangga Surabaya.

\section{METODE}

Penelitian ini menggunakan jenis penelitian quasi experiment design dengan pendekatan pre-post control group design.Jenis penelitian ini digunakan untuk mengetahui Perbedaan sebelum dan sesudah diberikan intervensi Pengetahuan, Sikap dan, Perilaku tentang Konsumsi Pangan Isoflavon pada Mahasiswi Alih Jenis dengan PreMenstrual Syndromedi Di Fakultas Kesehatan Masyarakat Universitas Airlangga Surabaya.
Rancangan penelitian ini membandingkan perbedaan intervensi pada kelompok perlakuan dan intervensi pada kelompok kontrol dengan tujuan untuk melihat perubahan pengetahuan, sikap dan, perilaku tentang konsumsi pangan Isoflavon pada Mahasiswi dengan kejadian Pre-Menstrual Syndrome. Penelitian ini dibagi menjadi dua kelompok, yaitu satu kelompok sebagai kelompok perlakuan dan lainnya sebagai kelompok kontrol. Untuk melihat pengaruh intervensi kelompok perlakuan diberikan pretest, pendidikan gizi, dan post-test. Pada kelompok kontrol diberiikan pre-test, tanpa pendidikan gizi dan post-test, sedangkan pada kedua kelompok sama-sama mendapatkan leaflet tentang macam-macam dan manfaat pangan isoflavon dalam penurunan gejala premenstrual syndrome. Penelitian ini dilakukan selama 1 bulan dengan frekuensi 4 kali pertemuan intervensi, durasi satu kali sesi adalah 60 menit dan pada setiap pertemuan dilakukan pemberian susu kedelai. Penilaian PMS dengan melakukan skrining awal menggunakan kuesioner Shortened Pramenstrual Assessment Form (SPAF) tentang gejala pre-menstrual syndromedengan skala 1-6 (1=tidak mengalami, 2=sangat ringan, 3=ringan, 4=sedang, 5=berat, 6=ekstrim) pada setiap pertanyaan kemudian diskoring. Hasil skoring di kategorikan menjadi PMS ringanskor $<30$, skor sedang lebih dari sama dengan $30 .{ }^{8}$

Sampel penelitian ini menggunakan kriteria inklusi dengan jumlah total sampel 38 responden terbagi menjadi 2 kelompok yaitu 19 responden kelompok perlakuan dan 19 reponden kelompok kontrol. Tehnik pengambilan sampel dalam peneltian ini menggunakan Simple Random Sampling yang merupakan teknik penarikan sampel yang didasarkan pada ciri atau karakteristik (tujuan) yang telah ditetapkan oleh peneliti sebelumnya. Pengambilan sampel secara acak dari total populasi yang homogen sesuai dengan kriteria inklusi antara lain: mahasiswi yang berumur 20-50 tahun, tidak sedang sakit, mengalami pre-menstrual syndrome 3 bulan 
berturut-turut dan bersedia mengisi mengikuti penelitian dan mengisi lembar persetujuan penelitian. Variabel pada penelitian ini meliputi pengetahuan, sikap, dan perilaku konsumsi pangan yang mengandung tinggi kadar isoflavon sebelum dan sesudah dilakukan intervensi pada mahasiswi dengan Pre-Menstrual Syndrome. Penelitian ini bertujuan menganalisis perbedaan antara pengetahuan, sikap, perilaku konsumsi pangan tinggi kadar isoflavon dan premenstrual syndrome sebelum dan sesudah diberikan intervensi pendidikan gizi antara kelompok perlakuan dan kelompok kontrol. Uji yang digunakan adalah uji independent $\mathrm{t}$ test.

Penelitian ini telah dipresentasikan pada Komisi Kaji Etik Fakultas Kesehatan Masyarakat Universitas Airlangga pada tanggal 09 November 2017 dengan nomor sertifikat 600-KEPK. Inform consent untuk responden penelitian telah didapatkan dari seluruh mahasiswi FKM UNAIR yang menjadi responden pada penelitian ini.

\section{HASIL DAN PEMBAHASAN}

\section{Analisis Karakteristik berdasarkan gejala Pre- Menstrual Syndrome}

Untuk mengetahui karakteristik umur responden, usiamenarche, uang saku dan ekonomi keluarga berdasarkan gejala PreMenstrual Syndrome dapat dilihat dari Tabel 1.

Analisis karakteristik umur responden mahasiswi Alih Jenis FKM UNAIR dari umur 2050 tahun, pada penelitian ini minimal umur 20 tahun dan maksimal usia 43 tahun. Responden yang mengalami gejala premenstrual syndrome sedang paling banyak pada umur 20-25 tahun (52,6\%), sedangkan responden yang mengalami gejala premenstrual syndrome ringan pada umur 20-25 tahun $(39,5 \%)$ Hasil persentase menunjukkan bahwa golongan umur 20-25 tahun lebih banyak mengalami gejala pre-menstrual syndrome tingkat sedang. Menurut penelitian yang sejenis bahwa, umur memiliki keterikatan terbalik dengan derajat keparahan pre-menstrual syndrome, semakin muda umur responden maka semakin berat derajat premenstrual syndrome. ${ }^{9}$

Analisis karakteristik usia menarche pada penelitian ini lebih dominan usia 13-14 tahun, bahwa usia menarche pada setiap orang berbeda paling sering terjadi pada usia 13 tahun, tetapi dapat juga menarche pada usia 10-16 tahun sehingga menyebabkan perbedaan derajat keparahan pre-menstrual syndrome yang dialami. Usia menarche secara umum usia 12-15 tahun, namun pada penelitian lain menjelaskan usia menarche yang tidak mengalami pre-menstrual syndrome pada usia 12-13 tahun sebanyak 23 responden. ${ }^{10}$ Penelitian yang sejalan bahwa usia menarche $>12$ tahun mengalami gejala pre-menstrual syndrome pada tingkat sedang. ${ }^{11}$ Usia menarche yang tertinggi pada kelompok usia 12-13 tahun dengan gejala premenstrual tingkat ringan sebesar $68,6 \%$ dan gejala pre-menstrual syndrome tingkat sedang sebesar $31,4 \% .^{12}$

Rata-rata uang saku yang didapat oleh responden adalah Rp.1.501.316 per bulan. Sebesar $44,7 \%$ responden mengalami gejala pre-menstrual syndrome sedang dengan uang saku dibawah rata-rata dan sebesar $26,3 \%$ yang mengalami gejala pre-menstrual syndrome ringan responden yang memiliki uang saku diatas rata-rata. Hasil ini menunjukkan bahwa uang saku yang dimiliki responden berfungsi untuk menmenuhi kebutuhan sehari-hari termasuk dalam membeli makanan yang akan dikonsumsi. Rata-rata ekonomi keluarga yang dimiliki oleh responden adalah $\mathrm{Rp} 5.210 .526$ per bulan.Sebesar 36,8\% ekonomi keluarga dibawah rata-rata lebih dominan memiliki gejala pre-menstrual syndrome sedangdibandingkan gejala pre-menstrual syndrome ringan memiliki hasil ekonomi keluarga diatas rata-rata sebesar $31,6 \%$. Ekonomi keluarga saling berkaitan dengan uang saku, jika ekonomi keluarga lebih dari 
Tabel 1. Karakteristik Responden Berdasarkan Gejala Pre-Menstrual Syndrome

\begin{tabular}{lcccc}
\hline \multirow{2}{*}{ Karakteristik responden } & \multicolumn{2}{c}{ PMS Ringan } & \multicolumn{2}{c}{ PMS Sedang } \\
\cline { 2 - 5 } & $\mathbf{n}$ & $\mathbf{\%}$ & $\mathbf{n}$ & $\%$ \\
\hline Umur Responden (tahun) & 15 & 39.5 & 20 & 52,6 \\
$\quad 20-25$ & 2 & 5,3 & 1 & 2,6 \\
$\quad 26-50$ & & & & \\
Usia Menarche (tahun) & 4 & 10,5 & 7 & 18,4 \\
$\quad 11-12$ & 13 & 34,2 & 14 & 36,8 \\
$\quad$ 13-14 & & & & \\
Uang saku (perbulan) & 7 & 18,4 & 17 & 44,7 \\
$\quad$ mean & 10 & 26,3 & 4 & 10,5 \\
$\quad$ mean & & & & \\
Ekonomi Keluarga (per bulan) & 5 & 13,2 & 14 & 36,8 \\
$\quad$ mean & 12 & 31,6 & 7 & 18,4 \\
\hline mean & & & & \\
\hline
\end{tabular}

Tabel 2. Perbandingan pengetahuan, sikap, dan gejala pre-menstrual syndrome sebelum dansesudah diberikan pendidikan gizi antara kelompok perlakuan dengan kelompok kontrol

\begin{tabular}{|c|c|c|c|}
\hline \multirow{3}{*}{ Variabel } & \multicolumn{2}{|c|}{ Kelompok } & \multirow{3}{*}{ p-value } \\
\hline & Perlakuan & Kontrol & \\
\hline & Mean \pm SD & Mean \pm SD & \\
\hline \multicolumn{4}{|l|}{ Sebelum: } \\
\hline Pengetahuan & $6,24 \pm 1,95$ & $6,21 \pm 1,08$ & 0,684 \\
\hline Sikap & $21,63 \pm 3,41$ & $20,31 \pm 2,49$ & 0,184 \\
\hline Gejala pre-menstrual syndrome & $29,16 \pm 6,76$ & $21,11 \pm 5,21$ & 0,382 \\
\hline \multicolumn{4}{|l|}{ Sesudah: } \\
\hline Pengetahuan & $8,53 \pm 1,21$ & $7,74 \pm 1,04$ & $0,039 *$ \\
\hline Sikap & $23,79 \pm 2,71$ & $21,89 \pm 2,10$ & $0,022 *$ \\
\hline Gejala pre-menstrual syndrome & $21,11 \pm 5,21$ & $26,42 \pm 7,05$ & $0,012^{*}$ \\
\hline
\end{tabular}

*signifikan menggunakan uji independent $t$-test, $\alpha=0,05$

nilai mean, maka mahasiswi lebih mudah menjangkau beragam jenis pangan yang memiliki tinggi kadar isoflavon sehingga gejala pre-menstrual syndrome dapat berkurang Wanita yang berpendapatan kurang dari $\$ 20.000$ pertahun lebih banyak mengalami PMS dengan persentase $8,4 \%$ dari pada wanita yang berpenghasilan $>\$ 20.000$ pertahun dengan persentase $6,5 \%{ }^{13}$

Analisis Perbedaan Sebelum dan Sesudah Perubahan Pengetahuan, Sikap, dan Perilaku Konsumsi Pangan Tinggi Kadar Isoflavon dengan gejala Pre-Menstrual Syndrome

Berdasarkan Tabel 2 menunjukkan bahwa hasil uji dengan menggunakan uji independent $\mathrm{t}$-test saat sebelum dan sesudah diberikan pendidikan gizi antara kelompok perlakuan dan kontrol. Perbedaan pengetahuan pada kelompok perlakuan terlihat setelah dilakukan intervensi pendidikan gizi terjadi peningkatan pengetahuan dari $(6,42 \pm 1,95)$ menjadi $(8,53 \pm 1,21)$ diketahui bahwa, peningkatan pengetahuan responden tentang pangan sumber isoflavon dapat menurunkan kejadian pre-menstrual syndrome dikarenakan edukasi yang diberikan selama 1 bulan dengan $4 x$ pertemuan sehingga menambah wawasan dan pengalaman responden terkait macammacam, manfaat serta fungsi dari pangan yang mengandung tinggi isoflavon dapat menurunkan gejala pre-menstrual syndrome. Pemberian intervensi pendidikan gizi tidak dilakukan pada kelompok kontrol akan tetapi diberikan leaflet terkait macam-macam 
pangan isoflavon dan manfaat dalam menurunkan gejala pre-menstrual syndrome dapat meningkatkan pengetahuan responden dari $(6,21 \pm 1,08)$ menjadi $(7,74 \pm 1,04)$. Hal ini didukung oleh penelitian lain menyatakan bahwa, tingkat pengetahuan siswa setelah dilakukan pemberian pendidikan kesehatan menggunakan media audio visual tentang premenstrual syndrome adalah kategori baik sebesar $61,67 \%$ dengan jumlah 37 siswi dan kategori kurang sebesar 3,33\% dengan jumlah 2 siswi. ${ }^{14}$ Jadi setelah diberikan pendidikan gizi terdapat perbedaan signifkan tingkat pegetahuan antara kelompok perlakuan dan kontrol dengan nilai p masing-masing 0,039.

Penelitian lain yang sejalan menjelaskan bahwa, pengontrolan gejala pre-mentrual syndrome dapat dilakukan dengan cara melakukan program pendidikan gizi. Manfaat program pendidikan PMS yang digunakan dapat memberikan dukungan untuk pendekatan multifaktoral terhadap intervensi. Dalam penelitian yang dilakukan juga menggunakan intervensi program pendidikan dengan metode pre-post test pada kelompok perlakuan dan kontrol. Hasil intervensi pada kelompok perlakuan nilai $p$ value sebesar 0,005 ada perbedaan total pre-menstrual syndrome sehingga dapat diartikan gejala PMS berkurang, sedangkan kelompok kontrol tidak signifikan dengan nilai sebesar 0,82 tidak ada perbedaan total pre-menstrual syndrome artinya masih terdapat gejala $\mathrm{PMS}^{15}$ Pengetahuan tentang isoflavon dan premenstrual syndrome saling berkaitan karena akan berdampak dalam upaya pengurangan keluhan PMS. Pengetahuan dapat diperoleh dari beberapa hal meliputi pengalaman, pedidikan sebelumnya atau lingkungan. Jika pengetahuan tentang isoflavon dan PMS baik, maka akan meningkatkan perilaku konsumsi pangan isoflavon sehingga PMS dapat berkurang. ${ }^{16}$

Perbedaan sikap pada kelompok perlakuan setelah dilakukan intervensi pendidikan gizi terjadi kenaikan dari $(21,63 \pm 3,41)$ menjadi $(23,79 \pm 2,74)$ dapat diketahui bahwa, sikap responden meningkat dikarenakan pengetahuan yang diterima responden cukup baik sehingga dapat merubah sikap responden. Hasil edukasi selama 1 bulan dapat mempengaruhi sikap responden untuk mengkonsumsi pangan sumber isoflavon dalam mengatasi gejala premenstrual syndrome yang alami. Metode yang diberikan pada pendidikan gizi ini meliputi: brainstorming, diskusi, memberikan buku kecil dengan mengajari mencatat gejala premenstrual syndrome pada buku tersebut dan mengajari aplikasi pengingat kalender menstruasi serta gejala menstruasi di handphone. Sikap positif terhadap konsumsi pangan isoflavon dibentuk melalui materi dan metode yang diajarkan oleh peneliti, dengan meningkatnya sikap terhadap konsumsi pangan isoflavon dapat diartikan frekuensi dalam mengkonsumsi pangan sumber isoflavon juga meningkat. Hubungan sikap dengan gejala pre-menstrual syndrome juga dijelaskan oleh peneliti lain bahwa, skor sikap negatif lebih tinggi daripada skor sikap positif, diketahui nilai positif sebesar $40 \%$,sedangkan sikap negatif sebesar $60 \%$ Jika hasil sikap positif lebih tinggi maka akan berpengaruh pada gejala pre-menstrual syndrome sehingga dapat menurunkan gelaja yang dialami ${ }^{16}$. Hubungan sikap dan pengetahuan dengan pre-menstrual syndrome memiliki hubungan yang erat, dijelaskan oleh peneliti lain terdapat nilai signifikan antara pengetahuan dan sikap sebesar $p<0,001$ yang berarti terdapat hubungan antara pengetahuan dan sikap yang dialami oleh remaja putri di SMA N 5 Surakarta. ${ }^{17}$

Pengaruh sikap responden juga memiliki banyak faktor yang mempengaruhi karena pembentukan tanggapan terhadap obyek merupakan proses kompleks dalam diri individu yang melibatkan individu yang bersangkutan, atau teman sebaya, keluarga yang mendukung dan menyuport. Selain itu situasi dimana tanggapan itu terbentuk, dan ciri- ciri obyektif yang dimiliki oleh stimulus juga termasuk dapat mempengaruhi sikap seseorang. Pengaruh kebudayaan salah satu mempunyai pengaruh besar terhadap 
pembentukan sikap terutama kebudayaan dimana hidup dan dibesarkan. ${ }^{18}$ Teori ini mendukung peningkatan yang terjadi pada kelompok kontrol bahwa, pada kelompok kontrol terjadi peningkatan dari $(20,31 \pm 2,49)$ menjadi $(21,89 \pm 2,10)$ namun peningkatan yang terjadi tidak sebanding dengan kelompok perlakuan yang diberikan intervensi pendidikan gizi, karena lebih tinggi peningkatan adanya stimulus dibandingkan dengan yang tidak diberikan. Hal ini didukung oleh penelitian lain bahwa, tidak terjadi peningkatan sikap responden setelah dilakukan intervensi peer group selama 4 minggu (nilai mean $0,38 \pm 5,98$ ) dengan nilai $p$ value 0,773 , disebabkan karena tidak ada dukungan dari teman sebaya sebagai model untuk dapat dicontoh, sebagai penunjuk untuk menumbuhkan rasa kebersamaan dan memiliki hubungan yang kuat dengan harga diri terkait nilai-nilai sama halnya dengan kelompok kontrol bahwa dengan adannya peer group akan lebih meningkatkan sikap yang dimiliki oleh responden. ${ }^{19}$ Namun dapat disimpulkan secara keseluruhan bahwa setelah diberikan pendidikan gizi antara kelompok perlakuan dan kelompok kontrol terjadi perbedaan yang signifikan sikap dengan nilai $p=0,022$.

Berdasarkan Tabel 3 dijelaskan bahwa, hubungan timbal baik antara personal dan lingkungan akan menghasilkan perubahan perilaku seseorang baik positif maupun negatif ${ }^{4}$. Terjadi peningkatan variasi jenis kelompok makanan pada kelompok perlakuan dan kelompok kontrol dari satu jenis kelompok makanan yaitu es susu kedelai menjadi beberapa jenis kelompok pangan yang lain antara lain: tempe goreng, tahu goreng, bawang putih, es susu kedelai dan susu kedelai dengan masing-masing nilai $(p=0,044),(p=0,036),(p=0,014),(p=0,044)$ dan $(p=0,004)$. Kenaikan es susu kedelai sebelum diberikan pendidikan gizi pada kelompok perlakuan $(5,78 \pm 4,35)$ sebanyak $1-2 x$ dalam seminggu menjadi $(24,63 \pm 13,64)$ yaitu sebanyak $6 x$ dalam seminggu. Pada kelompok kontrol dari $2 x$ dalam sebulan $(2,36 \pm 3,11)$ menjadi $3 x$ dalam seminggu $(12,52 \pm 21,21)$. Perubahan perilaku konsumsi pangan isoflavon pada kelompok perlakuan didapatkan dari metode edukasi yang diberikan meliputi: pemberian buku kecil untuk mencatat konsumsi makan dalam keseharian serta mengajarkan cara penimbangandan pemorsian macam-macam jenis pangan isoflavon sehingga responden termotivasi untuk mengkonsumsi pangan sumber isoflavon dengan intensitas frekuensi jumlah makanan lebih sering.

Hal ini dikuatkan darisalahsatureferensi dari BPOM yang menjelaskan bahwa, jumlah asupan isoflavon yang dibutuhkan oleh tubuh sebesar $50 \mathrm{mg} /$ hari meliputi: tempe $100 \mathrm{~g}$, tahu $200 \mathrm{~g}$, kacang kedelai $30 \mathrm{~g}$, taucho $100 \mathrm{~g}$, susu kedelai $500 \mathrm{ml} .{ }^{20}$ Anjuran konsumsi pangan nabati minimal $2 x$ sehari, sedangkan pada penelitian lain konsumsi tempe 2-3x/minggu, tahu 1-2x/minggu dan susu kedelai 0 $1 x /$ minggu masih tergolong rendah. ${ }^{21}$ Selain itu, edukasi yang dilakukan dalam penelitian ini adalah pemberian susu kedelai untuk menambah motivasi responden dalam mengkonsumsi salah satu produk olahan kacang kedelai yang tinggi kadar isoflavon. Kacang kedelai merupakan jenis makanan yang memiliki kaya akan kandungan kadar isoflavon yaitu $154,53 \mathrm{mg} / 100 \mathrm{gram}^{3}$. Adanya pemberian susu kedelai juga untuk meningkatkan perilaku konsumsi pangan sumber isoflavon sehingga akan mempengaruhi penurunan gejala premenstrual syndrome. Hal ini didukung dari hasil penelitian yang dilakukan gejala premensrual syndrome pada kelompok perlakuan terjadi penurunan dari $(29,16 \pm 6,76)$ menjadi $(21,11 \pm 5,21)$, sedangkan pada kelompok kontrol penurunan gejala pre-menstrual syndrome dari $(27,26 \pm 6,41)$ menjadi $(26,42 \pm 7,05)$. Namun pada kelompok kontrol hanya sedikit penurunan yang terjadi, dikarenakan pemberian susu kedelai hanya pada saat setelah post-test dilaksanakan. Penelitian lain yang membenarkan pengaruh isoflavon terhadap pre-menstrual syndrome dengan studi intervensi sebanyak 23 
responden usia 18-35 tahun terdapat pengaruh pada kelompok perlakuan setelah diberikan pengobatan aktif isoflavon kedelai sedangkan pada kelompok plasebo tidak signifikan. $^{22}$ Penelitian lain yang mendukung bahwa mengkonsumsi pangan yang tinggi kadar isoflavon dapat menurunkan estrogen dalam pre-menstrual syndrome dengan nilai $p=0,044 .^{23}$

Tabel 3. Perbandingan konsumsi pangan isoflavon Sebelum dan Sesudah Diberikan Pendidikan Gizi antara kelompok perlakuan dengan kelompok kontrol

\begin{tabular}{|c|c|c|c|}
\hline \multirow{3}{*}{ Variabel } & \multicolumn{2}{|c|}{ Kelompok } & \multirow{3}{*}{$p$-value } \\
\hline & Perlakuan & Kontrol & \\
\hline & Mean \pm SD & Mean \pm SD & \\
\hline \multicolumn{4}{|l|}{ Sebelum: } \\
\hline Brokoli & $2,42 \pm 2,03$ & $2,94 \pm 3,06$ & 0,537 \\
\hline Anggur & $4,48 \pm 5,00$ & $4,21 \pm 3,95$ & 0,668 \\
\hline Mayonnaise & $2,10 \pm 2,40$ & $2,94 \pm 3,13$ & 0,359 \\
\hline Tempe Olahan & $13,31 \pm 11,07$ & $19,26 \pm 14,73$ & 0,168 \\
\hline Tempe Goreng & $23,94 \pm 21,31$ & $32,31 \pm 21,67$ & 0,238 \\
\hline Tahu goreng & $18,89 \pm 17,92$ & $33,68 \pm 33,02$ & 0,095 \\
\hline Snack bar dari kedelai & $23,94 \pm 21,31$ & $32,31 \pm 21,67$ & 0,238 \\
\hline Biskuit & $19,57 \pm 16,62$ & $30,68 \pm 31,11$ & 0,178 \\
\hline Bawang putih & $30,94 \pm 27,49$ & $31,68 \pm 23,44$ & 0,930 \\
\hline Teh melati & $33,05 \pm 22,40$ & $26,63 \pm 20,73$ & 0,365 \\
\hline Es susu kedelai & $5,78 \pm 4,35$ & $2,36 \pm 3,11$ & $0,008^{*}$ \\
\hline Susu kedelai & $4,63 \pm 3,94$ & $6,73 \pm 13,45$ & 0,517 \\
\hline Jus jeruk dari konsentrat & $2,94 \pm 3,64$ & $6,21 \pm 6,92$ & 0,077 \\
\hline Ubi jalar & $0,78 \pm 0,91$ & $1,05 \pm 2,06$ & 0,615 \\
\hline Kopi & $4,42 \pm 7,14$ & $3,36 \pm 3,62$ & 0,570 \\
\hline \multicolumn{4}{|l|}{ Sesudah: } \\
\hline Brokoli & $7,57 \pm 3,67$ & $7,10 \pm 4,50$ & 0,725 \\
\hline Anggur & $7,84 \pm 3,53$ & $6,00 \pm 4,48$ & 0,169 \\
\hline Mayonnaise & $3,47 \pm 3,00$ & $2,68 \pm 2,38$ & 0,376 \\
\hline Tempe Olahan & $44,00 \pm 34,49$ & $28,63 \pm 23,87$ & 0,119 \\
\hline Tempe Goreng & $54,21 \pm 31,16$ & $34,10 \pm 28,20$ & $0,044 *$ \\
\hline Tahu goreng & $38,31 \pm 26,27$ & $22,57 \pm 17,27$ & $0,036 *$ \\
\hline Snack bar dari kedelai & $51,68 \pm 32,57$ & $34,10 \pm 28,10$ & 0,084 \\
\hline Biskuit & $50,52 \pm 30,74$ & $37,68 \pm 32,05$ & 0,216 \\
\hline Bawang putih & $63,78 \pm 26,69$ & $39,89 \pm 30,13$ & $0,014 *$ \\
\hline Teh melati & $30,52 \pm 21,93$ & $29,15 \pm 21,66$ & 0,848 \\
\hline Es susu kedelai & $24,63 \pm 13,64$ & $12,53 \pm 21,21$ & $0,044 *$ \\
\hline Susu kedelai & $21,93 \pm 10,94$ & $9,94 \pm 15,94$ & $0,004 *$ \\
\hline Jus jeruk dari konsentrat & $7,31 \pm 8,56$ & $6,15 \pm 8,56$ & 0,764 \\
\hline Ubi jalar & $3,47 \pm 6,58$ & $7,26 \pm 14,49$ & 0,307 \\
\hline Kopi & $4,94 \pm 8,92$ & $4,05 \pm 6,82$ & 0,731 \\
\hline
\end{tabular}

*signifikan menggunakan uji independent $t$-test, $\alpha=0,05$ 


\section{KESIMPULAN}

Pemberian intervensi pendidikan gizi dapat meningkatkan pengetahuan dan sikap responden yang cukup baik. Hal ini didukung dengan adanya sesi edukasi pada kelompok perlakuan selama 1 bulan dan pemberian susu kedelai pada setiap pertemuan yang dilakukan, sedangkan kelompok kontrol dari hasil leaflet yang diberikan dan post-test sehingga dengan adanya peningkatan pengetahuan dan sikap responden akan merubah perilaku responden dalam mengkonsumsi pangan isoflavon, dengan adanya perilaku konsumsi yang meningkat, maka gejalapre-menstrual syndrome pada mahasiswi Alih Jenis FKM UNAIR juga menurun secara perlahan. Walaupun belum semua jenis makanan yang tinggi kadar isoflavon dikonsumsi oleh responden dikarenakan keterbatasan waktu penelitian.

Hasil penelitian ini diharapkan dapat menjadi bahan penunjang informasi kepada semua institusi perguruan tinggi maupun swasta khususnya Mahasiswi Universitas Airlangga Surabaya terkait penambahan cara penanganan pre-menstrual syndrome dan perilaku dalam mengkonsumsi makanan yang memiliki tinggi kadar isoflavon sejak dini agar tidak mengganggu aktifitas sehari-hari.

\section{ACKNOWLEDGEMENT}

Terima kasih dan penghargaan diberikan penulis kepada seluruh staf pengajar Program Studi Kesehatan Masyarakat Universitas Airlangga atas bimbingan dan dukungan yang telah diberikan. Terima kasih kepada seluruh partisipan mahasiswi FKM UNAIR yang telah bersedia mengikuti penelitian ini.

\section{REFERENSI}

1. Saryono., Sejati, W. Sindrome Premenstruasi. (Nuha Medika, 2009).

2. Kridawati, A. Pemanfaatan Isoflavon Untuk Kesehatan. Respati I, 69-77
(2011).

3. Bhagwat, S., Haytowitz, D. B. \& Holden, J. M. USDA Database for the Isoflavone Content of Selected Foods. U.S. Department of Argiculture 1-156 (2011).

doi:http://www.ars.usda.gov/SP2UserFi les/Place/12354500/Data/isoflav/Isoflav -R2.pdf

4. Glanz, K., Rimer, B.K., Viswanath, K. Ecological models of health behavior. Health Behavior and Health Education: Theory, Research, and Practice (John Wiley and Sons, 2008). doi:10.7326/0003-4819-116-4-350_1

5. Contento, I. . Nutrition Education Linking Research, Theory an Practice. (Jones and Bartlett Publisher, 2011).

6. Chau, J.P.C., Chang, A. . Effects of an educational programme on adolescents with premenstrual syndrome. Health Educ. Res. 14, 817-830 (1999).

7. Ramadhani, R., Setiawati, O.R., Evayanti, Y. Analisis Faktor Yang Mempengaruhi Pre Mentrual Syndrome Pada Remaja Putri di SMPN 5 Bandar Lampung Tahun 2015. J. Dunia Kesmas 5, 65-73 (2016).

8. Rahayu, N.S., Safitri, D. . Hubungan Asupan Multivitamin dan Sindrome Pramenstruasi Pada Mahasiswi Gizi FKM UI. (Universitas Indonesia, 2016).

9. Anggrajani, F. \& Muhdi, N. Korelasi Faktor Risiko dengan Derajat Keparahan Premenstrual Syndrome pada Dokter Perempuan. (2018).

10. Devi, M. Hubungan kebiasaan makan dengan kejadian sindrom pramenstruasi pada remaja putri. Teknol. Dan Kejuru. 32, 197-208 (2010).

11. Nurmiaty., Wilopo, S. A., Sudargo, T. Perilaku Makan dengan Kejadian Sindrom Premenstruasi pada Remaja. Ber. Kedokt. Masy. 27, 75-82 (2012).

12. Ratikasari, I. Faktor yang berhubungan dengan kejadian pre-menstrual syndrome pada siswa SMA 112 Jakarta. (UIN Syarif Hidayatullah, 2015).

13. Deuster, P. A., Adera, T., S.-P. Biological, Social, and Behavioral Factors Associated With Premenstrual 
Syndrome. Arch. Fam. Med. 8, 122-128 (1999).

14. Jannah, R. Pengaruh Pendidikan Kesehatan Melalui Media Audio Visual Terhadap Peningkatan Pengetahuan Siswa Tentang Premenstrual Syndrome Di MTsN Seyegan Sleman. (Stikes Jenderal Achmad Yani Yogyakarta, 2014).

15. Endriani, V. Premenstruasi Syndrom Pada Remaja Putri Kelas X Smk Pgri 2 Kota Jambi. J. Akad. Baiturrahim 6, 1-6 (2017).

16. Silvia, M., K. Hubungan Pengetahuan tentang Sindrom Premenstruasi dan Motivasi Penanganan Sindrom Premenstruasi Remaja Putri dengan Penanganan Sindrom Premenstruasi Di SMA Muhammadiyah 5 Yogyakarta Tahun 2014. (Universitas 'Aisyiyah Yogyakarta, 2014).

17. Zulaikha, F. L. . Hubungan pengetahuan kesehatan reproduksi remaja putri terhadap sikap menghadapi premenstrual syndrome di SMA N 5 Surakarta. (Universitas Sebelas Maret, 2010).
18. Maulana. Promosi Kesehatan. (Salemba Medika, 2013).

19. Desmarnita, U., Djuwitaningsih, S., R. Pengaruh Pendidikan Kesehatan Metode Peer Group Terhadap Pengetahuan dan Sikap Remaja Putri Tentang Kesehatan Reproduksi. J. Keperawatan 2, 55-62 (2014).

20. Direktorat Standardisasi Produk Pangan. Pedoman Pangan Fungsional Edisi 1. (2004).

21. Zaddana, C. Konsumsi Makanan Sumber Isoflavon Serta Faktor-Faktor Lainnya terhadap Keluhan Premenstrual Syndrome (PMS) Pada Siswi SMA Di Bogor. (Institut Pertanian Bogor, 2014).

22. Bryant, M. et al. Effect of consumption of soy isoflavones on behavioural, somatic and affective symptoms in women with premenstrual syndrome. Br. J. Nutr. 93, 731 (2005).

23. Won, K. H., Kyoung, K. M., Sun, K. N. \& E., R. N. Intake of dietary soy isoflavones in relation to perimenstrual symptoms of Korean women living in the USA. Nurs. Health Sci. 8, 108-113 (2006). 